\title{
The meaning of phatic and conative interjections
}

\author{
Felix Ameka*
}

The purpose of this paper is to investigate the meanings of the members of two subclasses of interjections in Ewe: the conative/volitive which are directed at an auditor, and the phatic which are used in the maintenance of social and communicative contact. It is demonstrated that interjections like other linguistic signs have meanings which can be rigorously stated. In addition, the paper explores the differences and similarities between the semantic structures of interjections on one hand and formulaic words on the other. This is done through a comparison of the semantics and pragmatics of an interjection and a formulaic word which are used for welcoming people in Ewe. It is contended that formulaic words are speech acts qua speech acts while interjections are not fully fiedged speech acts because they lack illocutionary dictum in their semantic structure.

\section{Introduction}

This paper focuses on two classes of interjections: the conative ones which are directed at an auditor, and the phatic ones which are used in the maintenance of social and communicative contact (see introduction to this volume). Its purpose is to describe the meaning of a set of interjections in Ewe, a Kwa (Niger-Congo) language of West Africa, ${ }^{1}$ which fall into these classes.

Correspondence to: F. Amcka, Department of African Linguistics, University of Leiden, P.O. Box 9515, NL-2300 RA Leiden, The Netherlands.

* I would like to thank Lisette Frigo, Debbie Hill, Tim Shopen, Anna Wierzbicka and David Wilkins for their comments and suggestions on an earlier version of this paper.

1 Ewe, also spelt Eve, is spoken in the south eastern corner of Ghana across southern Togo as far as and just across the Togo-Benin border into Benin. It belongs to the Gbe subgroup of the Kwa subgroup of the Niger-Congo family. The normal orthography based on the African alphabet is used throughout the paper with the following modifications: (i) all high tones are marked with an acute accent ['] in addition to the low tones which are customarily marked by a grave accent [ ] . (ii) $\Phi$ is used for $f$. (iii) $v$ is the form for phonetic $\beta$. (iv) hyphens are introduced to show morpheme boundaries where relevant. Examples used in this study are drawn from both spoken and written standard Ewe. Some of the examples have been culled from prose fiction and drama written by native speakers of Ewe (see references). All interlinear and free translations are thosc of the author unless otherwise stated. The following abbreviations are used in the paper: $\mathrm{ADD}=$ addressive particle; $\mathrm{COMP}=$ complementiser; $\mathrm{DEF}=$ definite article; $\mathrm{DIM}=$ diminutive; aFOC $=$ argument focus marker; FUT $=$ future; HAB = habitual; INDEF = indefinite article; INGR = ingressive; IRR = irrealis; $N E G=$ negative; $N E R=$ nominaliser; NPRES = non-present; $\mathrm{PL}=$ plural marker; PRES $=$ present; $\mathrm{PROG}=$ progressive; $\mathrm{Q}=$ 
The main theoretical point of the paper is to demonstrate two things: first, that interjections like other linguistic signs have meanings which can be rigorously stated. It is argued that the functional and usage descriptions of interjections should be augmented with a description of their meanings which would constitute a reliable guide to their usage. The second thing is to show that there is a subtle difference between the semantic or conceptual structure of interjection words on the one hand and that of formulaic words on the other. In particular it will be demonstrated that formulaic words have the semantic structure of speech acts: they have both a dictum or propositional content in Searle's terms (Searle 1979) and an illocutionary purpose; however, interjections do not have such a dictum, but they may have a communicative function similar to the illocutionary purpose of formulae. To say that interjections do not have an illocutionary dictum is not to say that they do not have meanings. Rather, the claim is that interjections do have a semantic structure but this conceptual structure does not contain an illocutionary dictum. This second point is illustrated through a comparative analysis of the semantics of two forms atúù! and dzáà! both of which are used for welcoming people. It will be argued that atúù! is an interjection and dzáà! is a formulaic word. This difference is supported by a number of differences in their linguistic behaviour.

The Natural Semantic Metalanguage (NSM) method of semantic description and representation espoused by Wierzbicka $(1972,1980,1987,1989$, 1991, 1992b, among others) and others (e.g. Wilkins 1986, 1992; Goddard 1986, 1989; Ameka 1987, to appear a and b) is employed in the description of the meanings of the interjections and formulae. This method allows for the verification of the meanings of ideas with native speakers. Above all, it allows for a display of the subtle differences between the meanings of closely related utterances and thus facilitates their comparison. Thus it is hoped that the differences between the two types of utterances will be immediately revealed when the explications of their exemplars are compared.

The paper is organised as follows: in section 2 the contrast between interjections and formulaic words is examined through a comparative analysis of the semantics of the two expressions of welcome: atüu! and dzáà!. We will show that each of the items belongs to one type of word, and that the differences in their conceptual structures illustrate a difference between interjections and formulae. This is followed in section 3 by an investigation of the significance of expressions used to get people's attention and to communicate with people over a distance. $\Lambda$ set of vocalizations directed at animals in Ewe is also described. The paper concludes with a summary of the major points discussed.

question; $\mathbf{R E P}=$ repetitive; $\mathbf{S G}=$ singular; $\mathbf{S B J V}=$ subjunctive; VS $=$ verb satelite; $1=$ first person; 2 = second person; $3=$ third person. 


\section{Interjections vs. formulae: Speech acts and non-speech acts}

The discussion in this section is motivated by two related questions: (i) are interjections speech acts? and (ii) is there a semantic difference between interjections as a word class, and formulaic words? Different positions have been assumed with respect to these questions by some of the contributors to this issue. For instance, Wilkins (1992) argues that interjections are speech acts. He also claims that interjections and formulaic words have 'very similar semantic structure', although he concedes that formulaic words form a distinct semantic and pragmatic subtype of his very broadly defined large form class of interjections. Wierzbicka (1992a) on the other hand, contends that interjections do not have an illocutionary force. She asserts that they do not have any illocutionary components such as a dictum or an illocutionary purpose in their meaning. As such, she argues, they are not speech acts. Although Wierzbicka does not say anything explicitly concerning the relation between interjections and formulae, one can infer from her characterisation of interjections that they exclude formulae (see her criteria for defining interjections).

The position the present writer favours is somewhere between these two extremes. It seems clear, however, that the questions cannot be fruitfully answered one way or another in an empirical vacuum. There is a need for empirical investigations and detailed semantic analyses of the two types of words in different languages. My purpose in this section is to undertake such a study in a preliminary way based on one language. One assumption which is crucial to the ensuing discussion is that the meanings of linguistic items in general consist of components. More specifically, illocutionary meanings of speech acts are assumed to be amalgams of thoughts, feelings, intentions, purposes and propositions which a speaker conveys (see for example Searle 1979: 1-29; Norrick 1978; Van Dijk 1981: 215-241; Wierzbicka 1980, 1987, 1991; Ameka 1987, to appear a and b). It is reasonable to say that a linguistic sign whose meaning does not contain an illocutionary dictum is not a speech act. If this assumption is accepted, then I hope to demonstrate that interjections are not speech acts precisely because there is no illocutionary dictum in their semantic structure.

\section{1. atu่ù!}

As stated earlier, atúù! is an expression used to welcome people. It is used not only in Ewe but also in other languages of southern Ghana such as GaDangme and Akan. It may be glossed as 'I embrace you' because it is said by both the welcomer and the arriving person (that is, the one who is being welcomed) as they embrace each other. Typically one of the interlocutors initiates the encounter by stretching out his or her arms and uttering the first 
vowel [a] in a long drawn out manner until the two people come together and hug each other, and they both finish off with the rest of the expression [-túu. This action is usually followed by another welcoming expression addressed to the one who is arriving from some place. This implies that atúu! by itself is not complete as a welcoming act. Consider the following extract from a children's play:

(1) Av: agoo! agoo!

knock knock

G.: Al., ame adé le agoo dó ḿ yi

Al. person INDEF be:PRES knock say PROG go

na- kpo-e dá bé ameka- é máhã?

2SG:IRR see 3SG VS COMP who aFOC $Q$

Al.: ...Av. a...tuuu! ...

Av. EMBRANCE

wò- é- zo! wò- é- zo! wò- é- zo!

2SG aFOC walk 2SG aFOC walk 2SG aFOK walk

Av.: 'Knock, knock.' (litt.)

G.: 'Al. Someone is knocking (is saying 'knock'), go and investigate and see who it is.'

Al.: 'Av. a...tuuu! Welcome! Welcome! Welcome!' (Nunyams p. 13)

The context of this extract is this: Av. came from another village to visit Al. and $G$. He first calls attention to himself with the repeated use of the word agoo! outside their house (see Ameka (to appear a) for a description of this item). G. draws Al.'s attention to this and asks him to go and investigate. Al. comes out of the house and finds $G$. there and first embraces him and then adds other expressions of welcome. It should be noted that the initial [a] of atúu! is drawn out, indicated in writing by a series of dots. It should be pointed out also that the $[\mathrm{u}]$ vowel is lengthened (indicated by an additional ' $u$ ' in the writing in the extract). The lengthening of the vowels signals, I suggest, an emotive aspect of this expression. In this particular example this is reinforced by the repetition of the subsequent welcoming formula.

It can be said that atuit is used as an acknowledgement of the fact that the interlocutors who had not been in the same location previously are now in contact with each other. Through the mutual embrace and the simultaneous ultering of a...tuiuu!, both interlocutors express their pleasure to be in contact once more. This expression can be used by a child welcoming their parent home when the parent is coming back from the day's work, for example from the farm or the market. And it can also be used by parents to children when 
they are coming back from school for instance. Thus there is no constraint on the status of the status of the one who initiates this activity. Between adults, however, it tends to be used for an arriving person who has been away for a fairly long time. It is therefore unlikely that a husband and a wife would exchange atúu! when they return home after the day's work (in separate places). But they would if one of them had been away for a few days on a trip and comes back home. It seems therefore that when atüu! is used it can be assumed or it could be said that it feels like the participants have not been in contact for a long time. But the interpretation of 'long time' would appear to be different for children and for adults.

With these considerations in mind, the following explication is proposed for the meaning of this interjection:

atúù!

I know this: you and I are now in the same place

Before this time, you and I were not in the same place

I feel something good because we are now in the same place

I think you feel the same

I think we have not been in the same place for a long time

I want us to put our arms around each other because of this

I think you want us to do the same

We do this [embrace] at the same time as this: [túù] because we want to show how we feel

There are a number of features of this formula which are significant. One of them is the use of 'you and I' and 'we' in many places in the formula. This is meant to capture the simultaneous performance of the act. This indicates that this communicative act is a co-operative one. Observe that there is no separate response turn, but the summons and the response, so to speak, are embodied in one move.

Another feature of the formula worthy of note is that it does not have any reference to saying. The linguistic evidence for this is that atúu! cannot be reported with the verb dó 'say' as other expressions which have a saying component can. To report the action of atúù! one has to use the verb wo 'do'n. Thus one cannot *dó atúù, 'say atuu', but one has to wo atúù 'do atuu'. (Note that in the above extract G. reports the attention calling signal agoo of Av. with dó 'say' (see G.'s first line in the example above).) From this one can only infer that atúu! is construed as an acting out and not a saying. The activity consists of a vocal gesture accompanied by a physical gesture, but it is not viewed as a speech act.

It should also be noted that there is no sense in which one can talk of an addressee. One can talk of the target of the initiator's action or the intended interpreters of the communicative act but not an addressee. Thus in the above 
example, one can think of Av. as the target of the atúu! activity initiated by Al. Indeed that encounter could be reported as follows:

(2) Al. wo atúù ná Av.

Al. do embrace to Av.

(literally: Al. did atuu to Av.)

'Al. embraced or hugged Av.' (to welcome him).

Note that the target of the action is coded as a dative prepositional object. Some support for the contention that there is no addressee for the activity comes from the fact that atúu! cannot occur in the frame: "_ ná wò", that is, ' - to you' where the blank is filled by a linguistic expression which can stand on its own as an utterance and be addressed to someone else. The addressee is expressed as the object of the dative preposition. Thus one can have an addressee phrase with the form agoo! in the first line of the extract from the play above as occurs in the following example:

(3) agoo ná wò

to $2 \mathrm{SG}$

'Agoo to you!' (Dogoe 1964: 44)

However, atúu! cannot occur with such a phrase. Thus the following is unacceptable:

(4) *atúù ná wò

to $2 \mathrm{SG}$

We shall see in the next sub-section that an expression dzáa! which is functionally equivalent to atuiu! can occur with such an addressee phrase. This test provides justification for the claim that atúu! is an interjection while dzáà! is a formulaic word. Nevertheless, there is a 'you' in the explication of atuu!! It represents the person together with whom the initiator of atuu! acts out the rest of the gesture, the target of the initial action.

It is instructive to note that the form atúu can also be used adverbially to mean 'with open arms, cordially, kindly' (Westermann 1973). For instance,

(5) é- xo- awu lá atúù.

3SG get garment DEF cordially

'S/he received the garment gladly.'

This perhaps lends some support to the intuition captured in the explication that the initiator of the atúu! activity has some good feelings towards the 
target and they both share in the pleasure of being in the same place again after a period of separation. That is to say that the encounter is a cordial one.

It is very interesting that the polysemy of atúu! in Ewe described so far is also present in the other languages of southern Ghana where the form is used. For example, Kropp Dakubu (1973) has the following entry for atúu! in Ga, another Kwa language spoken to the immediate west of Ewe:

1. interjection: exclamation of welcome

2. adverb: gladly

It is hard to tell what the origin and path of diffusion of the form is within the linguistic area where it occurs. An investigation of the socio-historical spread of this and other items such as agoo! that are used widely across language boundaries in southern Ghana might shed some light on the cultural history of the linguistic groups in this area.

\section{2. dzáà!}

dzáà! is another expression which may be exclaimed usually repeatedly (at least twice or thrice) to signal the welcoming of someone. This expression is different from atúu! in a number of respects. The principal difference is that atúu! is an interjection while dzáa! is a formulaic word. I claim that this difference accounts for the difference in semantic structure between the two forms. Other differences tend to support this main contrast. Thus unlike atúŭ!, $d z a \dot{a}$ ! does not require a physical gesture, although it may be accompanied or followed by a hand-shake. In addition, unlike atuú!, there is a distinct response turn for $d z a ́ a ́$ !.

The dzáà! formula is a kind of general purpose welcoming salutation. It shows the pleasure of the speaker to have noticed the arrival or presence of the addressee. It is an enthusiastic acknowledgement from the speaker that the addressee is in the place where $s /$ he is. In some cases, the speaker proffers this either because $s /$ he is the first to notice the addressee or perhaps because $s /$ he arrived at the place before the addressee. For instance, when two people from different villages are visiting a festival ground in a different locality meet, one can salute the other with $d z a \dot{a} !$. The repetition of the form in the performance of the act is symptomatic, I suggest, of the good feelings that the speaker has towards the addressee.

One of the contexts in which this form is used is at public performances. Consider the opening words of a song that drama troupes typically sing as a curtain raiser to welcome their audiences:

(6) dzáà! dzáà! mié- le dzáà! dó- m má mi welcome welcome 1PL be:PRES welcome say PROG to $2 \mathrm{PL}$ 
dzáà! dzáà! nú- kpó- lá- wó. ... welcome welcome thing see NER PL 'Welcome! Welcome! We bid you welcome! Welcome! Welcome! the audience/spectators ...'

Note that the form is repeated in both instances in the example. It should also be noted that the delocutive form of the expression used makes use of the verb do 'say' in the first line.

$d z a \dot{a}$ ! is normally used in conjuction with another welcoming expression, typically $w \dot{o}-\dot{e}-z \jmath$ literally: 'you have travelled/walked'. ${ }^{2}$ It could precede or follow $w \dot{o}-\dot{e}-z \jmath$ as is evident from the examples below:

(7) A: dadaví, dzáà! dzáà! wò- é- zo madam, welcome welcome 2SG aFOC walk

'Madam, Welcome! Welcome! You have travelled.' (Setsoafia 1982: 100)

(8) Y: mia-wó- é zo, dzáà! dzáà!

2PL PL aFOC walk welcome welcome

'You have travelled, Welcome! Welcome!' (Setsoafia 1982: 100)

The inference to be drawn from this collocation of the form $d z a \dot{a} !$ with wó- $\dot{e}-$ $z o$ is that it is used to welcome someone who is construed as a "visitor" or who has travelled to some other place rather than just for someone who is returning home after the day's work, for example.

It has already been stated that there is a response turn to the $d z a \dot{a}$ ! formula. The addressee typically responds with dzáa!. An addressive particle such as goo 'I revere you' may be added to this response. Thus the following constitutes a typical adjacency pair (cf. Westermann 1930: 114):

(9) S.: dzáà! dzáà! dzáà!

welcome welcome welcome

$2 w \dot{o}-\dot{e}-z J$ is a speech formula which is used to welcome people in Ewe. As the literal meaning suggests, it is used to salute someone who is perceived to have travelled from a fairly distant place to the current place of encounter. This formula with its literal meaning of 'you have walked' is suggestive of the fact that the predominant means of transport of the Ewes before the advent of motor-cars etc. was by foot; although today the expression is used to welcome people irrespective of the means of transport used. This is an example of formulaic expressions being an embodiment of the socio-cultural history of the speech community in which they are used (cf. Ameka 1987. Coulmas 1981). The meaning of this expression may be represented as follows (compare this with the meanings of the other expressions of welcome discussed here):

wò $\dot{e}-\bar{z}$ )

I know you are now in the same place like me

I want you to feel something good when you are here

I want to say something to you because of that

I say: I know you have come from somewhere to this place

I say this because I want to cause you to feel something good when you are here 

A.: dzáà goo welcome ADD
S.: 'Welcome! Welcome! Welcome!'
A.: 'Thank you.'

Sometimes when dzáà! is used with wò-é-zo, it may be answered with yoo! 'OK' which is just a signal of acceptance of what has been said. For example, the response to (7) above was yoo!.

On the basis of these features of the use of dzáa!!, I propose the following explication to account for its use as a salutation:

\section{dzáà!}

I know this: you and I are now in the same place

I know you have come from some other place

I want to say something to you because of that

I say: I feel something very good because you are here

I say it because I want to show how I feel

I think you feel the same

I think you will say something of the same kind to me if you feel the same

The response of $d z a \dot{a} a$ ! conveys the message that the addressee is also pleased to be where s/he is. It is a return of the same kind of good wishes proffered by the speaker. This response may be paraphrased as follows:

\section{dzáà! (as response)}

I know you have said something very good to me because I am in this place I feel something good towards you because of that

I want to say the same kind of thing to you

I say: I fccl something good because you and I are in the same place

I say it because I want you to know I feel the same as you

\subsection{Interjections and illocutionary semantics $-A$ discussion}

In sections 2.1 and 2.2 the meanings of two functionally equivalent expressions, atúu!! and dzáă! in Ewe, were analysed. In the course of the exposition some differences between these forms were noted. By way of recapitulation, two of these differences are stated here: (i) atúu! is reported with the action verb wo 'to do' while dzáă! is reported with the illocutionary verb dó 'to say'; and (ii) atúù! does not have an addressee while dzáà! has one. These differences follow from or support the view that atúu! is an interjection and $d z a \dot{a} !$ is a formulaic word - a one-word routine.

If this assumption is correct and these differences are reflected in the semantic structures of these items, then a comparison of their explications 
should reveal some differences between the semantic structure of interjection words and formulaic words. One can also examine how far the semantic structures of these items have affinities with the prototypical structure of speech acts in order to determine whether interjections in particular are speech acts or not.

Perhaps the most noticeable difference between the explications proposed for the two forms above is that there is no component of the form: 'I say: ...' in the explication for atúu ! while there is one in that of dzáa!! In the NSM framework such a form is a paraphrase of the illocutionary dictum component of the meaning of an utterance. This means that there is no illocutionary dictum component in the semantic structure of atüu!, the form which we argue is an interjection. The dictum is a crucial component that the illocutionary forces of utterances should have. As Wierzbicka $(1980: 295)$ puts it: "the illocutionary force of an utterance contains at least two components one of which can be called ... the dictum, and the other ... the illocutionary purpose". From this point of view one could say that interjections do not have illocutionary dicta in their semantic structure.

To say that atúu! and for that matter interjections in general do not have dicta does not necessarily mean that they do not have illocutionary forces. There are other linguistic elements such as particles which have illocutionary forces but no illocutionary dicta in their structure (see below). The component of meaning which seems absolutely essential for one to say that a certain element has an illocutionary force seems to be illocutionary purpose. As Searle (1979: 3) observes, the most important component of the illocutionary force of a linguistic item is illocutionary purpose. The question that must be answered then is this: Do interjections have an illocutionary purpose component in their semantic structure?

Wierzbicka (1992a) contends that interjections do not have either a dictum or an illocutionary purpose component and therefore they do not have an illocutionary force. This conclusion would be correct if it was shown beyond doubt that there is indeed no illocutionary component in the conceptual structure of interjections. From the explications in the previous sections, it is clear that dzáà! has an illocutionary purpose component which in the NSM framework is represented in the form: 'I say this because ...'. Thus dzáà! has both a dictum and a purpose. It is thus a speech act in the full sense of the word.

The situation with atúu! is less clear: it does not have a dictum but it has a component which resembles an illocutionary purpose component. This component may be more appropriately described as representing the communicative purpose. The component in question is this: 'We do this [embrace] at the same time as this: [túü] because we want to show how we feel.' This component departs from the typical illocutionary component format in some respects. In particular it does not have a 'say' element and arguments have 
already been given to support this position. But this may be an idiosyncratic feature of atúu! and it may not necessarily be true of all interjections. Indeed as is shown in the next section on conative interjections most of them do have components similar to that of an illocutionary purpose with a 'say' in it. For example, the form $u: w u i$ ! which is used for hailing people in the bush or on the farm and for alerting them to something that is about to happen has this component (see section 3.1 below for justification):

I say this: [u:wúi] this way because

I want you to know that something is about to happen

I think you should know about it

Thus it would appear that interjections have a component which is comparable to an illocutionary purpose component in their meaning. For some interjections such as atüu! and English forms such as psst! or shh! this component starts off with a verb of doing, viz 'I do this: [vocal gesture] because ...'. For others, it is 'I say this [vocal gesture] because ...' (cf. Wilkins (1992) who argues that the illocutionary purpose of interjections has the form 'I say/do $[\mathrm{X}]$ because ...'). ${ }^{3}$

The general conclusion that may be drawn from the discussion so far is that interjections have a component in their conceptual structure which is very similar to the illocutionary purpose of utterances. If one accepts Searle's view that the illocutionary purpose is the most important component of the illocutionary force of a linguistic item, then one could say that interjections have an illocutionary force since they have a communicative purpose. But this illocutionary force does not contain an illocutionary dictum.

If this conclusion is correct, it would be consistent with the relationship that is assumed to exist between interjections and particles. In the illocutionary structure of particles, there is no dictum; particles modify the content of the proposition in which they occur. However, they have illocutionary purpose (see Goddard 1979 and the papers in Wierzbicka 1986). For example,

3 It should be pointed out that there is a difference between the way the illocutionary purpose component of a real speech act such as an imperative is interpreted and the way this component in the semantic structure of interjections is interpreted. For instance, an imperative such as Come here may be paraphrased into its essential illocutionary components as follows:

I say: I want you to come here

I say it because I want to cause you to do it.

In this formula the 'it' in 'I say it because' refers to the propositional content component rather than the utterance itself. In the component that resembles the illocutionary purpose in the semantic structure of interjections, the 'this' in that component refers to the utterance itself. On this score, one could argue that this component does not really spell out the illocutionary purpose but the conventional communicative purpose that uttering the interjection serves. This point deserves further investigation. At this stage, I leave the relationship between the two types of components an open question. 
propositional question forming particles such as $\grave{a}$ in Ewe have an illocutionary force which does not contain a dictum but includes an illocutionary purpose. The form $\dot{a}$ in Ewe is attached to declarative sentences to form propositional questions. Thus a sentence such as (10) below may be made interrogative as in (11) by the addition of the particle $\dot{a}$ :

(10) kofí dzó

'Kofi left'

(11) kofi dzó- à?

Kofi leave Q

'Has Kofi left?'

The propositional content of the utterances in (10) and (11) is the same and it may be roughly spelled out as follows:

\section{I say: Kofi left}

However, they differ in the rest of their illocutionary meanings. In particular the rest of the meaning of (11) is contributed by the particle $\dot{a}$ whose illocutionary force may be explicated as follows (see Ameka (to appear b) for justification and further illustration):

$\grave{a}$

I don't know if this (i.e. what I say) is true

I want to know it

I think you might know

I say it because I want to cause you to say something that would cause me to know it

Thus one could say that particles have illocutionary forces which do not have illocutionary dicta in much the same way that interjections which are sometimes classified as a subclass of particles do not have illocutionary dicta. But they do differ in the way the illocutionary purpose is interpreted (see footnote 3 above).

To conclude the discussion, one could say that interjections have a semantic structure which is different from that of formulae principally because they do not have an illocutionary dictum while formulae have such a mcaning component. Following from this one could further claim that interjections are not fully fledged speech acts because one would expect a speech act to have an illocutionary dictum. One word routines or formulae, however, are speech acts because they have the essential components that constitute such an act. Nevertheless, interjections do seem to have illocutionary meanings just as particles do. 


\section{Conative interjections}

In this section, various interjections that are used to hail people and animals in Ewe are described and semantic representations proposed for each of them to capture their usage. These are called conative because they are directed at someone else who may be expected to fulfill the wishes of the speaker (cf. Isačenko 1964; and the introduction to this volume (Ameka 1992)). The analysis of these forms also supports the claim that interjections are not speech acts in the sense that the semantic explications proposed for the various forms do not contain illocutionary dicta. The discussion will proceed as follows: Two forms used to communicate across a distance in the bush are discussed first (3.1). This is followed by a description of two other forms used to get people's attention (3.2 and 3.3). Variants of an interjection used to raise an alarm are examined next (3.4). Finally, various vocalisations for calling different animals are briefly described (3.5).

\section{1. ú:ru! and u:wüi!}

The two forms $\dot{u}: r u !$ and $u$ :wúi! could be considered as allo-lexemes, although one can note slight differences in their use and meaning. Basically, these two forms are used to call people across a distance in the bush or on the farm. For both forms, the interlocutor is not visible to the speaker. The speaker may use the form to locate the intended interpreter of the communicative act in the bush. They may also be used as prefatory summonses to giving information. For instance, on the farm, one could call to someone who is working in another part of the farm using either of the forms, when say food is ready or $\mathrm{s}$ /he wants to pass on some information. Consider the following exchange:

(12) A: ú:ru (ú:ru ...)

B: ú:ru

A: me- du ngo ló!

$1 \mathrm{SG}$ eat front $\mathrm{ADD}$

B: yoo, m'- a- va fifiá!

OK ISG IRR come now

A: 'I am taking the lead!' (I advise you): [i.e. I am going home ahead of you]

B: 'OK, I'll come soon.'

Notice that the interlocutor responds to the call with an identical form. This form appears to be similar to the Australian English cooee (see below). However, it seems that cooee is primarily used to locate people in the bush, while the Ewe forms may be used in circumstances where the speaker knows where the interlocutor is. These Ewe forms are used in such situations because 
there is a constraint on addressing people in the normal way in the bush for fear of evil spirits, for instance.

With these considerations in mind, the following explication is proposed for the meaning of $u$ :ru!:

u.ru!

I want to say something to you

I can't see you (here)

I think you are in a place where you can hearme

I want you to say the same kind of thing to me if you can hear me

I say: [ú:ru] because of this

By and large, the same formula would account for $u$ :wuil. Intuitively, however, one feels that $u$ :wuil has a warning sense enshrined in it which is absent from $u$ :ru! Some support for this claim comes from the tendency of $u: w u i$ ! to be used when there is some impending or imminent activity that the speaker wants someone to be aware of. For instance, if someone were in a dark forest and because of that s/he might not be aware of the thick clouds forming which signify that it is about to rain, the speaker may call to him/her using $u$ :wúi!.

Besides, $u$ :wúi! can just be used by itself without being directed at anybody in particular when clouds are forming and it is thundering. In this usage the form is an ejaculatory expressive which could be explicated as follows:

I now know something is about to happen

I feel something because of that

I say this: [u:wúi] because I want to show what I feel

As a summons, I suggest that $u$.wüi! has a component of 'I want you to know something is about to happen'. This component is absent from the formula for $\dot{u}: r u !$. The full meaning of $u$ :wui! as a call in the bush may be represented as follows:

u:wúi!

I want to say something to you

I can't see you

I think you are in a place where you can hear me

I want you to say the same kind of thing to me if you can hear me

I says this: [u:wúi] this way because

I want you to know that something is about to happen

I think you should know about it 
The two uses of u:wui! explicated here correspond to two classes of interjections: the expressive and the conative. Apart from showing that the same form can have different uses which relate to two classes, the situation described here provides a clue to the semantic basis of the classification of interjections according to the functions they perform. Essentially the two uses differ in their communicative purpose: the expressive is to show what the speaker feels or knows at the time of the utterance without necessarily being directed at anybody; and the conative is to seek the attention of the one to whom the form is directed.

In sum, $\dot{u}: r u$ ! and $u$ :wúi! are exclamatory summonses, but $u: w u ́ i !$ may also be used in a way in which it is not directed at another person - as an expression of the speaker's mental state. These forms are not formulae, but rather interjections because they do not have addressees. They cannot occur with an addressee phrase as one-word formulae can. Thus the following is unacceptable:

$$
\begin{aligned}
& \text { *ú:ru/ u:wúi ná wò } \\
& \text { to you }
\end{aligned}
$$

But they have an intended interpreter which is represented in the explications with you who is not conceptualised as an addressee. These forms may occur with the verb dó 'say' in delocutive function. This is the reason for having 'say' in the explications. Consider the following example:

(14) né e- vá dó agble- á lá, na

if 2SG come arrive farm DEF TP 2SG:IRR

dó ú:ru ná- $m$

say to $1 \mathrm{SG}$

'When you reach the farm, say uru to me.' (i.e. give me a yell)

It is interesting to compare the meanings of these forms that are used to communicate in the bush with that of a similar expression in Australian English, namely, cooee! The Macquarie dictionary defines it as 'a clear call, the second syllable of which rises rapidly in pitch, used most frequently in the bush as a signal to attract attention'. Its content has been more fully described by Wierzbicka (1991: 301) as follows:

cooee!

I know we are now in a kind of place where people can't see one another (if they are not in the same part of that place)

I can't see you

I think you are far away

I want to know where you are 
I want you to know where I am

I say this in this way because I want you to hear me

The crucial difference between cooee! and the Ewe forms lies in the fact that the former is used to locate people in the bush. In the explication above, this aspect of its meaning is represented by the components: 'I want to know where you are' and 'I want you to know where I am'. None of these components are part of the meaning of the Ewe forms. This difference shows the culture-specific and language specific nature of interjections which would otherwise appear to be functionally equivalent. It may well be that such forms for communicating over a distance are found in many languages but their specific meanings, I contend, will tend to be different. The value of detailed semantic descriptions of these forms is that they allow us to reveal such minute differences between seemingly equivalent forms across languages and cultures.

\section{2. ( $k$ ) ss...!}

kss...!, like he! (described below in 3.3), is used to call someone's attention over a distance (but not necessarily in the bush). The addressee is usually visible to the speaker, but the addressee may not be aware of the presence of the speaker. kss...! may be used just to draw someone's attention to something. It is thus not necessarily a summons although it can be, and it is not necessarily a conversation initiation marker. Thus if someone unknowingly dropped his/her handkerchief, an onlooker could draw his/her attention to it with kss...!. Hawkers at lorry stations and along the streets use this form very much (not only in Ewe country, but across Ghana) to draw the attention of passers-by to their wares.

$k s s . . . !$ may be accompanied by a clap. (Incidentally, a clap alone, without a vocalisation may be used as an attention-getter.) The one to whom kss...! is directed need not respond verbally. An action such as a turn around or even a startled jump could be a sufficient reaction to kss...! In this respect, kss...! is different from $u$ :ru! and $u$ :wúi! which elicit a verbal response. To account for this difference, I have proposed for kss...! a component of 'I want you to do something ...' instead of 'I want you to say the same kind of thing ...' which was proposed for ú:ru! and $u$ :wuil!.

$k s s .$. ! may be perceived as rude if a young person uses it to get the attention of an older person. This feature is not necessarily part of the meaning of kss...! The impoliteness stems, I think, from a violation of the 'social placedness' or appropriateness condition on such forms (cf. Evans to appear). For kss...! and also for he! (3.3) one could state the following condition of use:

A young person should not use this form to an older person 
More broadly this generalisation could be stated as follows:

People lower in social status should not use this form to their superiors

When this condition is violated, it triggers an inference, namely, impoliteness. In the explication of these forms there is no explicit statement on politeness because when kss...! and he! are used between equals, their use is not discourteous.

With these considerations in mind, I propose the following semantic formula for kss...!

kss...!

I think you do not know I am here

I want you to know I am here

I want you to hear me

I want you to do something to cause me to know that you can hear me

I say $[\mathrm{kss} . .$.$] because of that$

\section{3. he!}

The form he! is used in much the same way as kss...! to call people's attention. The addressee can be seen by the speaker and there need not be much distance between them. Typically some further communication takes place after this initial call. It can thus be said that he! may be used as a conversation initiator. Tentatively, one can propose the following explication for he! (compare it with the formula for kss...! above):

he!

I want you to know I am here

I want to say something to you

I want you to do something to cause me to know that you can hear me I say $[h \varepsilon]$ because of that

There are two main noticeable differences between the semantic formulae for kss...! and he!. First, for he! there is no assumption on the part of the speaker that the addressee is not aware of his presence as is the case for kss...! (cf. the first component in the formula for kss...). In fact he! may be used to alert an addressee who is in the same place as the speaker and with whom the speaker may have had prior interaction. Consider the following use of the form by a pacifist at a village meeting where a fight broke out between two other people:

$$
\begin{aligned}
& \text {...he, mi- tó } \\
& \text { 1PL stop } \\
& \text { 'Hey, stop it!' (Setsoafia 1982: 114) }
\end{aligned}
$$


In this example, the interlocutors had been communicating at the same place for some time and the form is used here to get their attention before further information is passed on.

Second, one expects some conversation to follow he!. This expectation is not associated with kss...! In example [16] below, a father had driven a suitor of his daughter away a few minutes earlier, he then notices that the suitor is coming back. The utterance is how he confronts him.

(16) hé de nè- ga- tró gbo- na lóo?

$Q$ 2SG REP turn come HAB $Q$

'Hey! Are you coming back or what?' (Setsoafia 1982: 41)

As the glosses suggest he! is functionally and perhaps semantically equivalent to English hey. Phonetically the two forms are different: English hey is pronounced [hei] while Ewe he! is [he]. The two forms are similar in that they can be used in conjunction with address terms to perform the summoning function. Compare the following forms:

Ewe: He Kofi! English: Hey Fred!
He Ama! Hey you!

Kss...! cannot be used in this way: ??Kss... Kofi!

Thus although kss...! and he! may be used to get people's attention they have slightly different meanings.

kss...! and he! are also different in the range of verbs that can be used to report them. kss...! can be reported either with do' 'say' or wo 'do', but he! can only be reported with dó 'say'. From this point of view, kss...! may be conceptualised either as a verbalization or as a vocalisation while he! is only viewed as a verbalisation. Thus if someone wanted to inquire as to whether $k s s .$. ! or he! were directed at him/her, s/he could use one of the following questions:

(17) nye- é nè- le kss do-/ wo- má ná- a?

1SG aFOC 2SG be:PRES say/ do PROG to Q

'Is it me you are saying/doing kss to?'

(18) nye- é né- le he do- $/{ }^{*}$ wo- mó ná- a?

1SG aFOC 2SG be:PRES say/ do PROG TO Q

'Is it me you are saying/*doing he to?'

Furthermore, kss...! and he! cannot take addressee phrases by themselves which suggests that they are prototypical interjections as opposed to formulae. The following are unacceptable expressions: 

(19a) *kss ná wò
to you
(19b) *he ná wò
to you

\section{4 búúbúi!}

Two phonological variants of this form are bóbóbói and bóbóbóe. This variation comes about in terms of the stricture created in the mouth for its production. The sound is made by striking one's palm against one's mouth with rounded lips and a stricture for the production of a non-low back vowel a number of times. This vocalisation is described in delocutive terms with the expression:

(20) $\Phi$ ú asi nu

hit hand mouth

[idiomatically: to raise an alarm]

Its nominalised form is asítunu as used in the following example. The context of example (21) is this: it was discovered that a young male guest of the chief of the village had eloped with one of the wives of the chief of the village, and the alarm and its response are described:

(21) asíøúnu di bóbóbó bé sala fia- srõ bú. du cry sound that $\mathrm{S}$. chief spouse lost village blíbo lá kátã Фo zi whole DEF all gather pile

'An alarm was raised that Sala, the wife of the chief, was missing. The whole town gathered to help (find her).' (Akpatsi 1980: 16)

The principal use of this form is that of raising an alarm to alert people to something bad that has happened or is happening and to get them to help in doing something to ameliorate the situation. Observe that in the above example, the whole town gathered to give help. This form is functionally equivalent to English cries of the form Help! (and in certain contexts to Fire!).

The Ewe cry may be produced as a reaction to a number of situations. For instance, it may be used when someone faints and people are needed to help resuscitate them. It may also be used to summon people when the news of the death of someone has been brought into the village. Consider the occurrence of bóbóbói in example (22) where it is attributed to the wife of one of two men who were fighting: 
(22) bóbóbóbóe! mi- nya aфé- á ná m loo, é- le 1PL chase home DEF for 1SG ADD 3SG be:PRES srõ- nye lá wu gé! spouse 1SG DEF kill INGR

'Help! Come and assist me! He is going to kill my husband!' (Gadzekpo 1982: 14)

It should be observed that in this example, the exclamatory or interjective summons is followed by an explicit invitation to come and help. Westermann (1973) glosses nya aфé-a ná ame as 'to assist a person in danger, distress or need'.

This call is different from the previous ones discussed in that it is not necessarily directed at an individual. Rather it is directed to members of a group - all people in the village or neighbourhood. It is usually very loud and sharp to produce the desired effect (to make your heart tick, so to speak). The utterer of this call would seem to be helpless because $s /$ he feels that $s /$ he cannot do anything alone or cannot do much about the situation alone hence the call for help.

I propose the following explication for bóbóbói!:

\section{bóbóbói/bóbóbóe/búbúbúi}

I know something bad has happened

I cannot do anything much about it

I feel something (bad) because of that

I think other people could do something about it

I want people to know that something bad has happened

I want people to come here and do something about it now

I say this: [bóbóbói/bóbóbóe/búbúbúi] because of that

I say it this way because I want people to hear me

I think people will do something that will cause me to know if they can hear me

The use of 'now' in various components of the formula is meant to reflect the urgency of the situation. Some of the time, some expertise is needed in handling the situation to which people have been called. For instance, it is medicine-men more than any other person who can help in resuscitating a person who has fainted. This is the reason for the use of 'other people' instead of just 'people'. It is hoped that such a phrase would be vague enough to cover situations in which there is no expertise required and those in which some special skills are necessary. ${ }^{4}$

4 A shorter form of this summons is used as a response cry to pain or fright, viz, búbúi! The same segmental form with low tone is also used to scare children: bubui!. The relationships between the forms are quite evident: they all have to do with something bad happening or that 


\subsection{Summonses for animals}

In the preceding sections, various interjections used to summon humans in Ewe were explored. This section presents an outline of the various ways in which one can call domestic animals: chickens, turkeys, ducks, goats, sheep, dogs, and cats. These summonses like the ones for humans have a conative function in the sense that they involve a wish on the part of the speaker for the animal to do something, either to go away or to come to him/her. They are thus used to demand an action from the animals to whom they are directed. One can divide the summons forms into lexical and phonation types. The phonation ones are the interjections, but to appreciate their significance it is useful to understand the lexical ones since both types may co-occur in one summons.

\subsubsection{Lexical summonses for animals}

All the different domestic animals may be called by their natural kind label and the diminutive suffix:

$\begin{array}{lll}\text { chickens: } & \text { kokló- } & \text { vi! } \\ & \text { fowl } & \text { DIM } \\ \text { sheep: } & \text { alế- } & \text { ví! } \\ & \text { sheep } & \text { DIM } \\ \text { goats: } & \text { gbs- } & \text { ví! } \\ & \text { goat } & \text { DIM } \\ \text { cats: } & \text { dadi- } & \text { ví! } \\ & \text { cat } & \text { DIM } \\ \text { dogs: } & \text { avu- } & \text { ví! } \\ & \text { dog } & \text { DIM }\end{array}$

Turkeys and ducks are usually called by their bare label without the diminutive suffix:

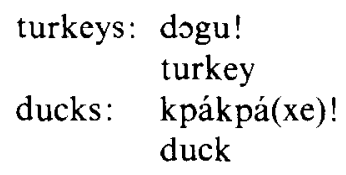

It is possible that turkeys are not summoned with the diminutive form because of their size. They are not very easy to handle either. There is an appellation based on the comparison between the size of turkeys and cattle which is sometimes used to summon them: 
(23) dogu, nyi lolo wú wò! turkey, cow big surpass $2 \mathrm{SG}$

'Turkey, the cow is bigger than you!'

$\Lambda$ s for ducks, it seems that they are not called with the diminutive form because people think of them as dirty birds.

Animals that have 'personal' names may be summoned by their names. Names are usually given to dogs and less frequently to cats. Sheeps, goats, ducks, turkeys and fowls do not get personal names. Examples of dog-names comparable to Fido in English are:

\section{nyásã 'Wisdom' dódzi 'Perseverance'}

\subsubsection{Phonation summonses for animals}

The lexical summonses may be accompanied by phonations or the phonations may be used by themselves to call the animals. For sheep and goats one can imitate their bleating: mbhe...! mbhe...!. A lateral click [S] produced several times may also be used to call these animals. Summoning goats and sheep is invariably effected by a combination of the lexical call and one of the phonations. Food is sometimes used as a bait for them when they are being called. Hence the summons forms may be followed by an invitation such as

(24) vá xo!

come receive!

'Come and get!'

A typical call of sheep may have the following form:

(25) alẽ- ví! (alẽ- ví)! JJJ (vá xo) (vá xo)

sheep DIM sheep DIM clicks come receive come receive 'Sheep! Sheep! Come and get come and get!'

Cats are usually summoned by the form:

$$
\text { pu...s! pus, pus, pus! }
$$

Variants, or rather forms identical to this one seem to be rather widespread for calling cats. It is found in Europe, for example, in Norway and the UK, and Bynon (1976: 59-60) reports its use in Morocco by the Berber.

And domestic birds, fowls, turkeys and ducks are called by the form:

krú! krú! krú!... 
There does not seem to be any special phonation for calling dogs. The form lés! lés! may be used to urge them to chase animals in the bush. ${ }^{5}$

The conative function of all the phonation forms for summoning animals may be represented as follows:

I want you (this animal) here!

I do this: [phonation] because of that

\subsubsection{Forms for sending animals away}

Just as there are forms for calling animals to oneself, so are there forms for sending them away. For sheep and goats the form kái! is used. Dogs and cats are sent away by the form $s \tilde{a}$ !. Domestic birds are driven away by the form súi!. Each of these may be accompanied by a gesture, usually the use of a whip. One can explicate these forms as follows:

\section{kái! \\ I don't want you (sheep/goat) here \\ I want you (sheep/goat) to go away from here \\ I say this: [kái] because of that \\ sán! \\ I don't want you (cat/dog) here \\ I want you (cat/dog) to go away from here \\ I say this: [sã́] because of that}

súi!

I don't want you (bird) here

I want you (bird) to go away from here

I say this: [súi] because of that

Alternatively, these forms could be defined as follows:

kái!

I don't want this sheep/this goat here

I want this sheep / this goat to go away from here

I say this: [kai] because of that

$s \tilde{a} !$

I don't want this cat/ this dog here

I want this cat/ this dog to go away from here

I say this: [sã்] because of that

"The form lés! seems to be based on the verb lé 'catch'. The source of the 's' on the end is not entirely clear to me although one can think that it comes from English. lés! may be glossed, I think, as 'catch it'. 
sủi!

I don't want this bird here

I want this bird to go away from here

I say this: [súi] because of that

The alternatives represent two different theoretical positions on animal address. For the first set, it is assumed that the animals are the intended interpreters of the communication event or auditors to whom humans direct their speech. Hence the use of 'you' in the formulae. For the second set, by contrast, the animals are not presented as direct addressees. The emphasis is more on the wants of the speaker. The choice of one set or the other depends on the position one takes as to "whether addressing animals can be considered as a linguistic manifestation in the full sense of the word, i.e. as 'glottic' phenomenon in O. Jespersen's terminology" (Isačencko 1964: 95). As Isačenko goes on to point out "Utterances made to animals differ from those in a normal linguistic situation in that the addressee is not in command of the linguistic system. But since we have to do with utterances in which phonemic material is used we may affirm that calls to animals still belong to glottic phenomena. These calls ... have the status of collective conventional signals" (1964: 95).

The first set of formulae in which the animals are presented as addressees may be preferred, because it could be argued that the animals whose calls are described here are reared as free-range domestic animals; hence they perhaps have some command of the forms that are directed at them. Indeed, one can ask someone to say these forms to the animals as in the following examples:

(26) dó kai ná gbo lá
say to goat DEF
'Say 'kai' to the goat.'
(27) dó súi ná koklo- á
say to hen DEF
'Say 'sui' to the hen.'

These examples show that the forms are reported with the verb do 'say' and also that they are directed at the animals.

The calls could be thought of as constituting a register of the language with its special features such as the interlocutors being animals. Bynon (1976: 63) has compared this kind of language with nursery language and observes that in both registers it is not essential that the utterance as a whole be comprehensible to the interlocutor. It could be assumed that the animals respond to the acoustic signals rather than to the content of the utterance. 


\section{Conclusion}

In this paper, it has been argued and hopefully demonstrated that interjections are meaningful, not only in the functional sense, but also in their content. Thus the description of interjections in this paper does not stop at assigning them functions such as conative or phatic; rather explicit semantic representations have been proposed for each item from which, it is hoped, one could predict the range of uses to which a particular item may be put.

In addition, the point has also been made and illustrated in a rudimentary way that the semantic structure of interjections is different from that of formulaic words. Consequently, it is suggested that these two types of words should be distinguished. The essential difference between them is that formulaic words are fully fledged speech acts: they have the conceptual structure of illocutionary acts, while interjections lack an illocutionary dictum (or propositional content) in their semantic structure. I venture to suggest that lexemes which may constitute utterances by themselves without being elliptical have different degrees of affinity with or resemblance to prototypical speech acts. At one end of the continuum are conventional vocalisations which make use of sounds and phonological structures which are not part of the main sound system. For instance, English brr! 'I feel cold', psst! 'I want silence', and the dental clicks /tsk, $t s k /$ ! Note that these are reported with the verb 'go' as in 'Psst', she went (cf. Wilkins 1992). Roughly speaking the semantic structure of such interjections have the following elements:

\section{I feel/think/ want $\mathrm{X}$}

I do this: [vocal gesture] because of that

In the middle of the continuum are those verbalisations which are more integrated in the linguistic system and are reported with the verb 'say'. Examples here include wow! 'I am surprised', aha! 'I understand', oops! 'I am embarrassed'. These, I suggest have a structure of the form:

I feel/think/want $\mathrm{X}$

I say this: [vocal gesture] because of that

These two points on the continuum are filled by interjections, but at the other end of the scale are formulae and lexical items which are interactional and are speech acts. Some English examples are: goodbye!, welcome!, sorry!, and thankyou!. These could be said to have the following skeletal components in their structure:

I say: $X$

I say it because I want you to ... 
One way of looking at this continuum is in terms of conventionalization of lexemes: "from symptoms ... to consciously selected signals" (Haiman 1989: 159, and see also Stankiewicz 1964, Trager 1964). Or it may be viewed as a hierarchy of lexemic utterances from mental acts to speech acts. Whichever way one looks at it, one thing is certain: there is the need for further investigation into the semantic structures of these lexemic utterances to establish their relationship to other utterances.

\section{References}

Ameka, Felix, 1987. A comparative analysis of linguistic routines in two languages: English and Ewe. Journal of Pragmatics 11(3): 229-326.

Ameka, Felix, 1992. Introduction - Interjections: The universal yet neglected part of speech. Journal of Pragmatics, 18: 101-118 (this issue).

Ameka, Felix, to appear a. 'Agoo can be English!' can it? On the semantic representation of linguistic routines. In: David Wilkins, ed., Conceptual primitives and semantic analysis. Berlin: Mouton.

Ameka, Felix, to appear b. Discovering the meaning of illocutionary particles: A study in Ewe semantics and pragmatics. Berlin: Mouton.

Bynon, James, 1976. Domestic animal calling in a Berber tribe. In: William C. McCormack and Stephen A. Wurm, eds., Language and man: Anthropological issues, 39-65. The Hague: Mouton.

Coulmas, Florian, 1981. Introduction. In: Florian Coulmas, ed., Conversational routine, 1-17. The Hague: Mouton.

Delridge, Arthur, 1981. The Macquarie dictionary. Sydney: Macquarie Library.

Evans, Nicholas, to appear. Code, inference, placedness and ellipsis. In: William A. Foley, ed., The role of theory in language description. Berlin: Mouton de Gruyter.

Goddard, Cliff, 1979. Particles and illocutionary semantics. Papers in Linguistics. 9: 185-227.

Goddard, Cliff, 1986. The natural semantics of too. Journal of Pragmatics 10(5): 635-644.

Goddard, Cliff, 1989. Issues in natural semantic metalanguage. Quaderni di Semantica 10(1): 5I64.

Haiman, John, 1989. Alienation in grammar. Studies in Language. 13(1): 129-170.

Isačenko, A. V., 1964. On the conative function of language. In: J. Vachek, ed., A Prague School reader in linguistics, 88-97. Bloomington, IN: Indiana University Press.

Kropp Dakubu, Mary Esther, 1973. Ga-English dictionary. Legon: Institute of African Studies.

Norrick, Neal R., 1978. Expressive illocutionary acts. Journal of Pragmatics 2: 277-291.

Searle, John, 1979. Expression and meaning. Cambridge: Cambridge University Press.

Stankiewicz, Edward, 1964. Problems of emotive language. In: T. Sebeok, A. Hayes and M. C. Bateson, eds., Approaches to semiotics, 239-264, The Hague: Mouton.

Trager, George L., 1964. Paralanguage: A first approximation. In: Dell Hymes, ed., Language in culture and society, 274-288. New York: Harper and Row.

Van Dijk, Teun A., 1981. Studies in the pragmatics of discourse. The Hague: Mouton.

Westermann, Dietrich, 1930. A study of the Ewe language [translated by A.L. Blickford Smith]. London: Oxford University Press.

Westermann, Dietrich, 1973. Ewefiala: Ewe-English Dictionary. Berlin: Reimer. [1928]

Wierzbicka, Anna. 1972. Semantic primitives. Frankfurt: Athenäum.

Wierzbicka, Anna. 1980a. Lingua mentalis: The semantics of natural language. Sydney: Academic Press.

Wierzbicka, Anna, ed., 1986. Special issue on 'Particles'. Journal of Pragmatics 10(5). 
Wierzbicka, Anna, 1987. English speech act verbs: A semantic dictionary. Sydney: Academic Press.

Wierzbicka, Anna, 1989. Semantic primitives: The expanding set. Quaderni di Semantica 10(2): $133-157$.

Wierzbicka, Anna, 1991. Cross-cultural pragmatics: The semantics of human interaction. Berlin: Mouton de Gruyter.

Wierzbicka, Anna, 1992a. The semantics of interjection. Journal of Pragmatics 18:159-192 (this issue).

Wierzbicka, Anna, 1992b. Lexical universals and universals of grammar. In: Michel Kefer and Johan van der Auwera, eds., Grammar and meaning: Cross-linguistic perspectives, 383-415. Berlin and New York: Mouton de Gruyter.

Wilkins, David, 1986. Particles/clitics for criticism and complaint in Mparntwe Arrernte (Aranda). Journal of Pragmatics 10(5): 575-596.

Wilkins, David, 1992. Interjections as deictic. Journal of Pragmatics 18: 119-158 (this issue).

\section{Ewe texts}

Akpatsi, Robert S., 1980. ame adeke menya etso me o [Nobody knows tomorrow]. Accra: Bureau of Ghana Languages.

Bidi Setsoafia, H.K., 1982. fia tsatsala [The wandering chief]. Accra: Bureau of Ghana Languages.

Dogoe, E. Y., 1964. nya zozo [Know how to walk]. Accra: Bureau of Ghana Languages. [Third edition]

Gadzekpo, B.S., 1982. ewots ku, equla li [The producer is dead the consumer is alive]. Accra: Waterville Publishing House. [Second revised edition]

Nunyamo [The way to knowledge]. Accra: Bureau of Ghana Languages. 